\title{
Preparation of Polysaccharide Nanofiber Fabrics by Electrospray Deposition: Additive Effects of Poly(ethylene oxide)
}

\author{
Hiroshi Seo, ${ }^{1}$ Hidetoshi Matsumoto, ${ }^{1}$ Satoshi Hara, ${ }^{1}$ Mie Minagawa, ${ }^{1}$ \\ Akihiko TANIOKA, ${ }^{1, \dagger}$ Hiroshi YAKo, ${ }^{2}$ Yutaka YAMAGATA, ${ }^{3}$ and Kozo INOUE ${ }^{4}$ \\ ${ }^{1}$ Department of Organic and Polymeric Materials, and International Research Center of Macromolecular Science, \\ Tokyo Institute of Technology, Mail Box S8-27, 2-12-1 Ookayama, Meguro-ku, Tokyo 152-8552, Japan \\ ${ }^{2}$ Kyowa Tecnos Co.,Ltd., 2759-3 Koike, Shibayama-cho, Sanbu 289-1624, Japan \\ ${ }^{3}$ Materials Fabrication Laboratory, The Institute of Physical and Chemical Research (RIKEN), \\ 2-1 Hirosawa, Wako 351-0198, Japan \\ ${ }^{4}$ Fuence Co., Ltd., 703 AIOS Hiroo Bldg., 1-11-5 Hiroo, Shibuya-ku, Tokyo 150-0012, Japan
}

(Received November 4, 2004; Accepted March 10, 2005; Published June 15, 2005)

\begin{abstract}
Polysaccharide—chitosan, sodium chondroitin sulfate, and pectin—nanofibrous fabrics were prepared from the respective polysaccharide/poly(ethylene oxide) (PEO) blend solutions by electrospray deposition (ESD). The surface morphologies of the electrosprayed fabrics were observed by scanning electron microscopy (SEM). Unblended polysaccharide solutions showed low ESD processability; viz., the solutions could not be electrosprayed, or provided a non-fibrous morphology composed of spherical entities when ESD was applicable. The addition of high-molecular-weight PEO $\left(M_{\mathrm{w}}=500,000\right)$ to chitosan solutions significantly enhanced the formation of a fibrous structure. Sodium chondroitin sulfate/PEO and pectin/PEO blend solutions were generally too viscous to be sprayed at $25^{\circ} \mathrm{C}$; at $70^{\circ} \mathrm{C}$, however, we succeeded in forming the fibrous structure from these solutions by ESD. The results indicate that adequate heating is effective to improve the processability of such highly viscous blend solutions into the electrostatic fiber formation. [DOI 10.1295/polymj.37.391]

KEY WORDS Polysaccharides / Chitosan / Sodium Chondroitin Sulfate / Pectin / Nanofiber / Electrospray Deposition /
\end{abstract}

Electrospray deposition (ESD) is a straightforward and versatile method for forming thin films. This method has the following advantages: (i) applicability to solute molecules which have a wide range of molecular weights (e.g., inorganic molecules, synthetic polymers, proteins, and DNA); and (ii) ability to deposit polymer thin films with nano-microscaled structures, which range from spheres to fibers. ${ }^{1-10}$ The ESD methods consist of the following steps: (i) a strong electric field is applied between a polymer solution placed in a nozzle and a conductive substrate; (ii) when the voltage reaches a critical value, electrostatic forces overcome the surface tension of the solution; (iii) charged droplets (or jets) are sprayed from the tip of the nozzle, in a dry atmosphere; and (iv) the dried droplets (or jets) are finally collected on the substrate to form a thin film. One major advantage of the ESD technology is forming nano-microscaled fibrous fabrics (typically nonwoven fabrics).

Chitosan, which is obtained by deacetylation of chitin in concentrated alkaline solution at a high temperature, is one of the muco-polysaccharides with a $\beta-1,4$ bonded structure of the glucosamine residue, having an amino group at the $\mathrm{C}-2$ position and two hydroxyl groups at the C-3 and C-6 positions. ${ }^{11}$ Chondroitin sulfate is widely distributed over the inside of human body in the form of proteoglycan which is combined with non-collagenic protein, as a matrix component such as cartilage, tendons, blood vessel walls and skins. ${ }^{12}$ It is an acidic muco-polysaccharide, which consists of $\mathrm{N}$-acetyl-D-galactosamine and uronic acid and is extracted from shark or bovine cartilage. Pectin is a vegetative phlegmatic material widely distributed over the leaves, stalks, and fruits of seaweeds and plants. It is formed in a $\beta-1,4$ bonded structure with D-galacturonic acid partially methyl-esterified. ${ }^{13}$ These polysaccharides have high biocompatibility, biodegradability, and bioactivity such as wound healing and antimicrobial effects. ${ }^{14-16}$

There have been many studies on electrostatic fiber formation, or "electrospinning". ${ }^{17-19}$ Electrostatic fiber formation has drawn strong attention in many fields including biomedical engineering (e.g., scaffolds for tissue engineering ${ }^{20}$ and drug delivery systems ${ }^{21}$ ). The combination of functional biomacromolecules, polysaccharides, and nano-microfabrication technology, ESD, is a promising option to provide novel biomedical devices. Since polysaccharide

${ }^{\dagger}$ To whom correspondence should be addressed (Tel: +81-3-5734-2426, Fax: +81-3-5734-2876, E-mail: atanioka@o.cc.titech.ac.jp). 
solutions generally show a lower ESD processability, water-soluble polymer may be useful as the additive of polysaccharide solution to improve the electrostatic spinnability. Several papers have been published on the electrostatic fiber formation of polysaccharides and their mixtures with water-soluble polymers $(e . g$., cellulose,${ }^{22}$ dextran, ${ }^{23}$ hyaluronic acid, ${ }^{24}$ chitin, ${ }^{25}$ chitosan, ${ }^{26}$ a chitosan/poly(ethylene oxide) (PEO) mixture, ${ }^{27}$ a chitosan/poly(vinyl alcohol) (PVA) mixture, ${ }^{26}$ and cellulose acetate/PVA mixtures ${ }^{28}$ ). However, there have been few systematic studies on the additive effect of water-soluble polymers on the electrostatic spinnability of polysaccharide solution. To the best of our knowledge, the electrostatic fiber formation from sodium chondroitin sulfate and pectin solutions has never been accomplished.

Our previous paper provided a systematic information for the morphology control of PEO thin films by ESD. ${ }^{8}$ In the present work, we attempt to thoroughly examine the additive effect of PEO, which is a biocompatible polymer, ${ }^{29}$ to solutions of different polysaccharides, chitosan, sodium chondroitin sulfate, and pectin, on forming their fibrous structure. The aim of this paper is to present a comprehensive findings on the electrostatic spinnability from the polysaccharide/ PEO blend solutions by ESD.

\section{EXPERIMENTAL}

\section{Materials}

Three chitosans, with mutually different average molecular weights, $M_{\mathrm{w}}=36,000(\mathrm{CH}-36 \mathrm{k}$; Degree of deacetylation, $\mathrm{DAC}=87 \%), 70,000 \quad(\mathrm{CH}-70 \mathrm{k}$; $\mathrm{DAC}=85 \%)$, and $120,000(\mathrm{CH}-120 \mathrm{k} ; \mathrm{DAC}=85 \%)$, were supplied from Kyowa Tecnos, Japan. Sodium chondroitin sulfate of $M_{\mathrm{w}}=110,000(\mathrm{CHON})$ and pectin of $M_{\mathrm{w}}=510,000$ (PEC) were purchased from Laiyang Xianghe Biochemical Products, China, and Wako Pure Chemicals, Japan, respectively. The molecular weights of these polysaccharides were estimated by gel permeation chromatography using an apparatus equipped with a column (Shodex Asahipack GF7MHQ, Showa Denko, Japan) and a refractive index detector (L-7490, Hitachi, Japan). 0.2 M Acetic acid$0.2 \mathrm{M}$ sodium acetate buffer was used as an eluent. Poly(ethylene oxide)s of nominal average molecular weights, $M_{\mathrm{w}}=20,000$ (PEO-20k), 100,000 (PEO$100 \mathrm{k}$ ), and 500,000 (PEO-500k), were purchased from Wako Pure Chemicals, Japan (for PEO-20k and $-500 k$ ) and Polysciences, USA (for PEO-100k). Acetic acid of extra-pure grade was obtained from Wako Pure Chemicals, Japan.

Ultrapure water was prepared in a water purification system (Milli-Q Academic A10, Millipore, USA) and used in the preparation of aqueous polymer solutions.

Aluminum sheets (AL-013 Series, Nilaco, Japan) were used as a conductive substrate.

\section{Preparation of Spray Solutions}

Chitosan $(\mathrm{CH})$ was dissolved in $5 \mathrm{wt} \%$ acetic acid aqueous solution to give a $10 \mathrm{wt} \% \mathrm{CH}$ solution (chitosan:acetic acid = 2:1 w/w). On the other hand, $5 \mathrm{wt} \%$ PEO aqueous solutions were prepared using three kinds of PEOs with different molecular weights. A CH-36k solution was blended with the $5 \mathrm{wt} \%$ PEO solutions at volume proportions 8:2, 6:4, 4:6, and 2:8. The actual blending ratios of the two polymer solutes, $\mathrm{CH}-36 \mathrm{k} / \mathrm{PEO}$, are $8 / 1,6 / 2,4 / 3$, and $2 / 4 \mathrm{in} \mathrm{w} / \mathrm{w}$ for the three kinds of blended systems, CH-36k/PEO20k, CH-36k/PEO-100k, and CH-36k/PEO-500k. Two additional solutions of $\mathrm{CH}-36 \mathrm{k} / \mathrm{PEO}-500 \mathrm{k}=$ 9.5/0.25 and 9/0.5 were also prepared.

Sodium chondroitin sulfate (CHON) aqueous solutions were prepared at 1,10 , and $20 \mathrm{wt} \%$. They were blended with a $5 \mathrm{wt} \%$ PEO-500k solution at volume proportions of $8: 2,6: 4,4: 6$, and 2:8; corresponding to actual solute ratios of $0.8 / 1,0.6 / 2,0.4 / 3$, and $0.2 / 4(\mathrm{w} / \mathrm{w})$ for $1 \mathrm{wt} \% \mathrm{CHON} / \mathrm{PEO} ; 8 / 1,6 / 2,4 / 3$, and $2 / 4(\mathrm{w} / \mathrm{w})$ for $10 \mathrm{wt} \% \mathrm{CHON} / \mathrm{PEO}$; and $16 / 1$, $12 / 2,8 / 3$, and $4 / 4(\mathrm{w} / \mathrm{w})$ for $20 \mathrm{wt} \% \mathrm{CHON} / \mathrm{PEO}$.

Pectin (PEC) aqueous solutions were prepared at 1 , 3 , and $5 \mathrm{wt} \%$. They were blended with a $5 \mathrm{wt} \%$ PEO500k solution at volume proportions of 8:2, 6:4, 4:6, and $2: 8$. The blending ratios of the solutes are $0.8 / 1$, $0.6 / 2,0.4 / 3$, and $0.2 / 4(\mathrm{w} / \mathrm{w})$ for $1 \mathrm{wt} \% \mathrm{PEC} / \mathrm{PEO}$; $2.4 / 1,1.8 / 2,1.2 / 3$, and $0.6 / 4(\mathrm{w} / \mathrm{w})$ for $3 \mathrm{wt} \% \mathrm{PEC} /$ PEO; and $4 / 1,3 / 2,2 / 3$, and $1 / 4(\mathrm{w} / \mathrm{w})$ for $5 \mathrm{wt} \%$ $\mathrm{PEC} / \mathrm{PEO}$.

Solution viscosities were measured with an oscillating type viscosity meter (VM-100A, CBC Materials, Japan) at $25^{\circ} \mathrm{C}$ and $70^{\circ} \mathrm{C}$. Surface tensions of the polymer solutions were determined by the Whilhelmy plate method using a full automatic surface tensiometer (CBVP-Z, Kyowa Interface Science, Japan) at $25^{\circ} \mathrm{C}$. Solution conductivities were measured using a conductivity meter (CM-20S, TOA, Japan) equipped with a conductivity cell (CG-511B, TOA, Japan) at $25^{\circ} \mathrm{C}$.

\section{Electrospray Deposition (ESD)}

Electrospraying was carried out using an electrospray deposition device (ESD200S, Fuence, Japan), which is shown in Figure 1. Polymer solutions were sprayed through a glass capillary with an internal platinum microelectrode. Glass capillaries of $50 \mu \mathrm{m}$ diameter were prepared using a glass microelectrode puller (PC-10, Narishige, Japan). The distance between the capillary tip and the substrate surface was $80 \mathrm{~mm}$. The voltage applied between the capillary and the substrate was typically $6.4-16.6 \mathrm{kV}$ corresponding to 


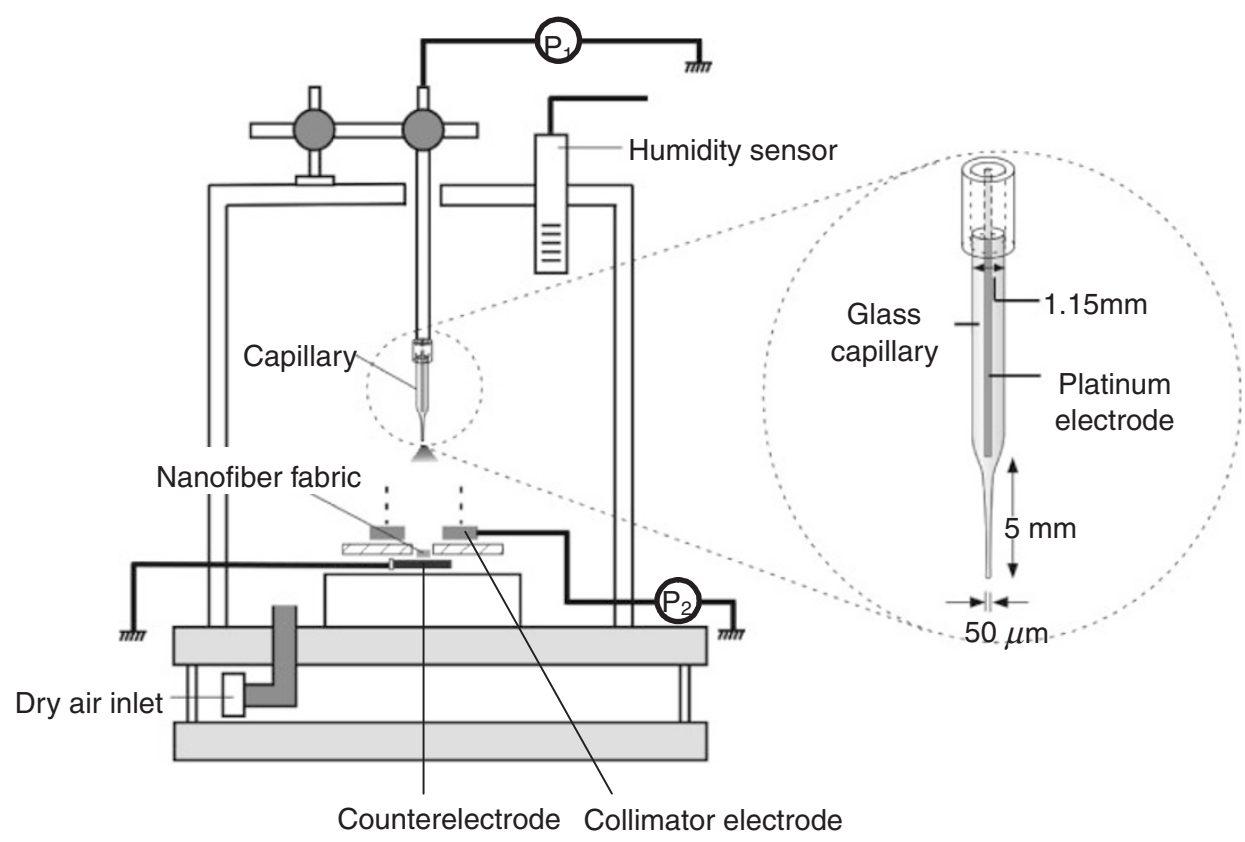

Figure 1. Schematic diagram of the ESD device. P1, DC power source for ESD; P2, DC power source for collimator.

near the lower critical spraying voltage for each solution. Deposition was performed in an acrylic chamber filled with dry air (typically the relative humidity is $20 \%$ and the temperature is about $25^{\circ} \mathrm{C}$ ).

\section{Observation of Surface Morphologies of Fabrics}

The surface morphologies of the deposited thin fabrics were observed using a scanning electron microscope (SEM; SM-200, Topcon, Japan) operated at 4$7 \mathrm{kV}$. All samples were sputter-coated with Au.

\section{Fourier Transform Infrared Spectroscopy (FT-IR)}

Infrared spectra were measured with a Fourier transform infrared spectrometer (FT/IR-410, JASCO, Japan) with 16 scans at a $4 \mathrm{~cm}^{-1}$ resolution from 4000 to $400 \mathrm{~cm}^{-1}$.

\section{RESULTS AND DISCUSSION}

\section{ESD of Unblended Chitosan Solutions}

Before examination of PEO addition effect, we tried to deposit from unblended chitosan solutions. Here, we prepared three kinds of $10 \mathrm{wt} \%$ chitosan solutions with different molecular weights, $\mathrm{CH}-36 \mathrm{k}$, $\mathrm{CH}-70 \mathrm{k}$, and $\mathrm{CH}-120 \mathrm{k}$. The viscosity of the chitosan solutions became higher conspicuously as the molecular weight rose. We could deposit thin fabrics from the $\mathrm{CH}-36 \mathrm{k}$ solution at $25^{\circ} \mathrm{C}$, but their surface morphology was usually made up of spherically structured entities. To the contrary, the $\mathrm{CH}-70 \mathrm{k}$ and $\mathrm{CH}-120 \mathrm{k}$ solutions were unable to be sprayed even at $20 \mathrm{kV}$. (Our previous study showed that the drawing of a higherviscosity solution in a capillary by electrostatic force was more difficult. ${ }^{8}$ ) When the $\mathrm{CH}-70 \mathrm{k}$ and $\mathrm{CH}-$ $120 \mathrm{k}$ solutions were heated at $70^{\circ} \mathrm{C}$, however, it became possible to spray them due to the decrease in solution viscosity. Even then, again we obtained only spherically structured deposits from these solutions.

\section{Additive Effects of PEO on ESD proccesabilty of Chi- tosan Solutions}

It has been found so far that the addition of watersoluble polymer can improve the electrostatic spinnability. ${ }^{26-28,30}$ In the present study, we used CH-36k showing a good ESD processability previously mentioned, and three kinds of PEOs, PEO-20k, PEO$100 \mathrm{k}$, and PEO-500k, as additives. The basic properties and spinnability of the prepared $\mathrm{CH} / \mathrm{PEO}$ solutions are summarized in Table I. Figure 2 shows the effect of molecular weight of adding PEO on the surface morphologies of electrospray-deposited fabrics from $\mathrm{C} 2, \mathrm{C} 7$, and $\mathrm{C} 15$ solutions, where the $\mathrm{CH}$ concentration and $\mathrm{CH} / \mathrm{PEO}$ ratio are fixed at $6 \mathrm{wt} \%$ and $6 / 2$, respectively. The SEM data given there indicate that the addition of higher-molecular-weight PEO tends to develop a fibrous structure. Our previous study revealed that plain high-molecular-weight PEO showed good spinnability. ${ }^{8}$ As can be seen in Table I, the conductivity of $\mathrm{CH} / \mathrm{PEO}$ blend solutions increased with an increase in the $\mathrm{CH}$ concentration. Therefore, applied voltages, which are near the lower critical spraying voltage, also increased with an increase in the $\mathrm{CH}$ concentration. (Our previous study demonstrated that the charging of higher-conductivity solution at the tip of the capillary under application of voltage was more difficult. ${ }^{8}$ ) Figure 3 shows the poly- 


\section{H. SEO et al.}

Table I. Properties of $\mathrm{CH} / \mathrm{PEO}$ blend solutions and their spinnability by ESD*

\begin{tabular}{|c|c|c|c|c|c|c|c|c|c|c|c|}
\hline $\begin{array}{l}\text { Spray } \\
\text { Solution }\end{array}$ & $\begin{array}{c}\mathrm{CH}^{\mathrm{a}}-36 \mathrm{k} \\
(\mathrm{g})\end{array}$ & \multicolumn{2}{|c|}{$\begin{array}{c}\mathrm{PEO}^{\mathrm{b}} \\
(\mathrm{g})\end{array}$} & $\begin{array}{c}\mathrm{HAc}^{\mathrm{c}} \\
(\mathrm{g})\end{array}$ & $\begin{array}{l}\text { Water } \\
(\mathrm{g})\end{array}$ & $\begin{array}{l}\text { Conductivity } \\
(\mathrm{mS} / \mathrm{cm})\end{array}$ & $\begin{array}{l}\text { Viscosity } \\
\text { (mPas) }\end{array}$ & $\begin{array}{l}\text { Surface tension } \\
(\mathrm{mN} / \mathrm{m})\end{array}$ & $\begin{array}{c}\text { Spraying } \\
\text { Temp. }\left({ }^{\circ} \mathrm{C}\right)\end{array}$ & $\begin{array}{c}\text { Spraying } \\
\text { Voltage }(\mathrm{kV})\end{array}$ & $\begin{array}{c}\text { Surface } \\
\text { morphology }\end{array}$ \\
\hline $\mathrm{C} 1$ & 8 & $20 \mathrm{k}$ & 1 & 4 & 87 & 9.34 & 58.2 & 56.4 & 25 & - & - \\
\hline $\mathrm{C} 2$ & 6 & & 2 & 3 & 89 & 7.58 & 35.9 & 56.9 & 25 & 16.54 & spherical \\
\hline $\mathrm{C} 3$ & 4 & & 3 & 2 & 91 & 5.86 & 20.0 & 56.0 & 25 & 16.54 & spherical \\
\hline $\mathrm{C} 4$ & 2 & & 4 & 1 & 93 & 3.84 & 10.7 & 52.9 & 25 & 13.58 & spherical \\
\hline $\mathrm{C} 5$ & 0 & & 5 & 0 & 95 & 0.0948 & 4.5 & 61.3 & 25 & 6.47 & spherical \\
\hline C6 & 8 & $100 \mathrm{k}$ & 1 & 4 & 87 & 9.33 & 79.8 & 57.6 & 25 & 14.40 & spherical \\
\hline $\mathrm{C} 7$ & 6 & & 2 & 3 & 89 & 6.89 & 62.1 & 55.9 & 25 & 14.00 & spherical \\
\hline $\mathrm{C} 8$ & 4 & & 3 & 2 & 91 & 5.21 & 48.2 & 54.4 & 25 & 11.54 & spherical \\
\hline C9 & 2 & & 4 & 1 & 93 & 3.09 & 36.2 & 55.0 & 25 & 11.28 & spherical \\
\hline $\mathrm{C} 10$ & 0 & & 5 & 0 & 95 & 0.191 & 25.0 & 60.9 & 25 & 8.50 & spherical \\
\hline C11 & 10 & $500 \mathrm{k}$ & 0 & 5 & 85 & 10.4 & 82.9 & 61.6 & 25 & - & - \\
\hline $\mathrm{C} 12$ & 9.5 & & 0.25 & 4.75 & 85.5 & 10.2 & 92.5 & 61.2 & 25 & 16.54 & $\mathrm{~s} / \mathrm{f} \mathrm{mixture}^{\mathrm{d}}$ \\
\hline $\mathrm{C} 13$ & 9 & & 0.5 & 4.5 & 86 & 9.91 & 95.5 & 61.0 & 25 & 14.70 & fibrous \\
\hline $\mathrm{C} 14$ & 8 & & 1 & 4 & 87 & 9.40 & 117 & 61.6 & 25 & 12.61 & fibrous \\
\hline $\mathrm{C} 15$ & 6 & & 2 & 3 & 89 & 7.56 & 126 & 60.0 & 25 & 11.20 & fibrous \\
\hline C16 & 4 & & 3 & 2 & 91 & 5.36 & 130 & 59.2 & 25 & 10.86 & fibrous \\
\hline $\mathrm{C} 17$ & 2 & & 4 & 1 & 93 & 2.92 & 146 & 57.9 & 25 & 9.08 & fibrous \\
\hline C18 & 0 & & 5 & 0 & 95 & 0.0374 & 197 & 63.4 & 25 & 6.80 & fibrous \\
\hline
\end{tabular}

${ }^{\mathrm{a}} \mathrm{CH}$ : chitosan; ${ }^{\mathrm{b}} \mathrm{PEO}$ : poly(ethylene oxide); ${ }^{\mathrm{c}} \mathrm{HAc}$ : acetic acid; ${ }^{\mathrm{d}} \mathrm{s} / \mathrm{f}$ mixture: mixture of spherical and fibrous shapes.

${ }^{*}$ All solution properties were measured at $25^{\circ} \mathrm{C}$.

a

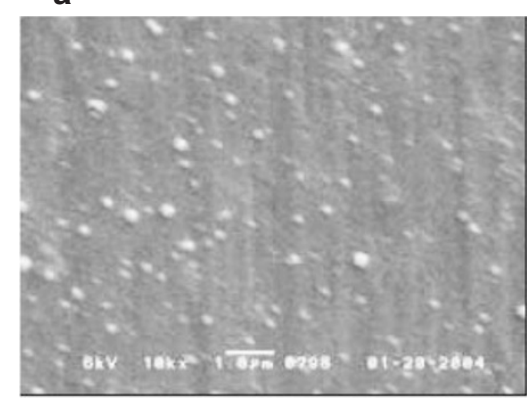

b

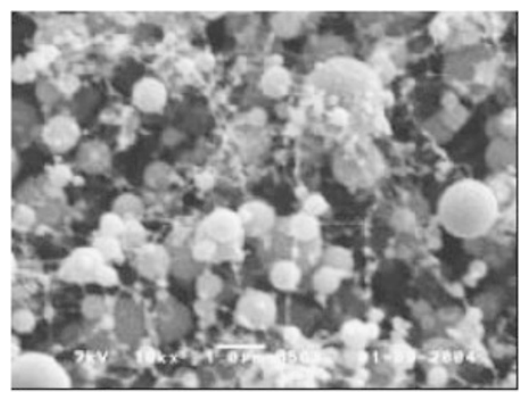

c

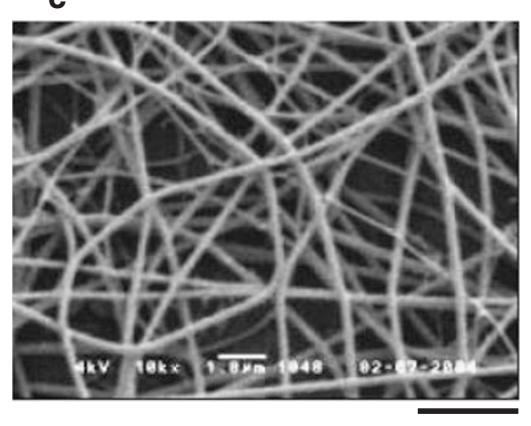

$2 \mu \mathrm{m}$

Figure 2. Effect of molecular weight of adding PEO on the surface morphology of electrospray-deposited $\mathrm{CH} / \mathrm{PEO}$ blend fabrics: sprayed from (a) C2, (b) C7, and (c) C15 solutions (see Table I).

mer composition dependence of the viscosity and electrostatic spinnability for $\mathrm{CH} / \mathrm{PEO}$ blend solutions C1-C18 (see Table I). The viscositiy of the blend solutions decreased with an increase in the $\mathrm{CH} / \mathrm{PEO}$ ratio for the CH-36k/PEO-500k solutions (C11-C18), because the value for the $5 \mathrm{wt} \% \mathrm{CH}-36 \mathrm{k}$ (C11) solution, $82.9 \mathrm{mPas}$, is smaller than that for the PEO-500k (C18) solution of the same concentration, $197 \mathrm{mPas}$. Conversely, the viscosity of the CH-36k/PEO-20k and $\mathrm{CH}-36 \mathrm{k} / \mathrm{PEO}-100 \mathrm{k}$ blend solutions increased with an increase in the $\mathrm{CH} / \mathrm{PEO}$ ratio, because the value for the $5 \mathrm{wt} \% \mathrm{CH}-36 \mathrm{k}(\mathrm{C} 11)$ solution, 82.9 $\mathrm{mPas}$, is larger than those for the PEO-20k (C5) and PEO-100k (C10) solutions of the same concentration, 4.5 and $25.0 \mathrm{mPas}$, respectively. All the solutions with higher viscosity than $95.5 \mathrm{mPas}$ showed good spinna- bility: the spray solutions with the higher-molecularweight $\mathrm{PEO}$ and/or the lower $\mathrm{CH} / \mathrm{PEO}-500 \mathrm{k}$ ratio (i.e., higher PEO concentration) tend to form the fibrous structure by ESD. The tendency corresponds to the effect of solution viscosity described in our previous paper. ${ }^{8}$ This result also confirmed that the addition of such a small content of PEO-500k, whose concentration in the blend solution is $0.5 \mathrm{wt} \%$ (C13), was already effective for the fiber formation. An effect of the $\mathrm{CH} / \mathrm{PEO}$ ratio on the diameter of produced fibers for CH-36k/PEO-500k blend fabrics is shown in Figure 4 . The fiber diameter increased rapidly at $\mathrm{CH}-$ $36 \mathrm{k}$ contents higher than $75 \mathrm{wt} \%$ from 150 to $350 \mathrm{~nm}$. Figure 5 shows an FT-IR spectrum of an electrospraydeposited $\mathrm{CH} / \mathrm{PEO}$ fabric prepared from the $\mathrm{C} 15$ solution, in comparison with that of a pure PEO fabric 


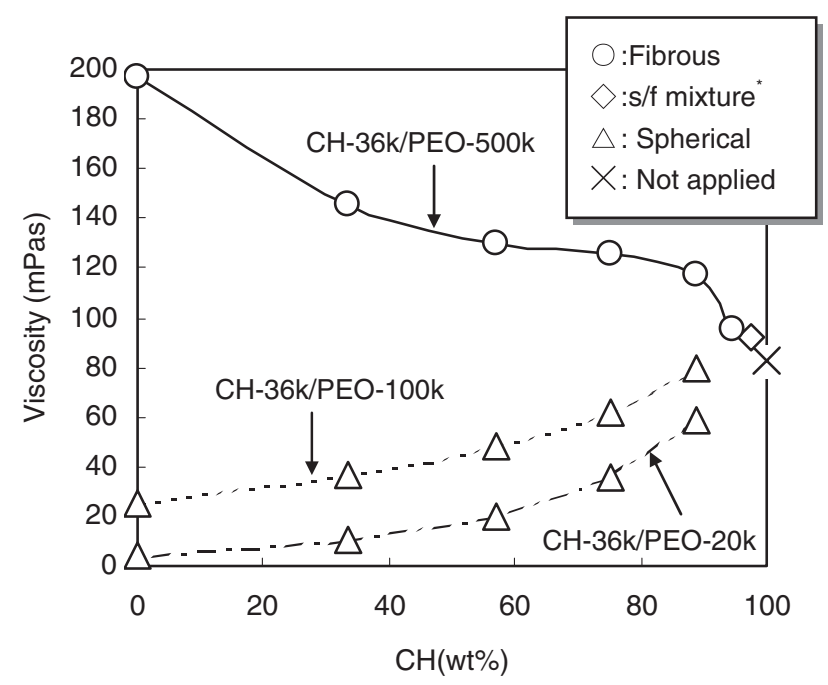

Figure 3. Polymer composition dependence of the viscosity and electrostatic spinnability for $\mathrm{CH} / \mathrm{PEO}$ blend solutions $\mathrm{C} 1-$ $\mathrm{C} 18$ (see Table I). The composition is denoted by wt $\% \mathrm{CH}$ calculated as $\mathrm{CH} /(\mathrm{CH}+\mathrm{PEO})(\mathrm{w} / \mathrm{w}) \times 100 \%$. ${ }^{*}$ s/f mixture: mixture of spherical and fibrous shapes.

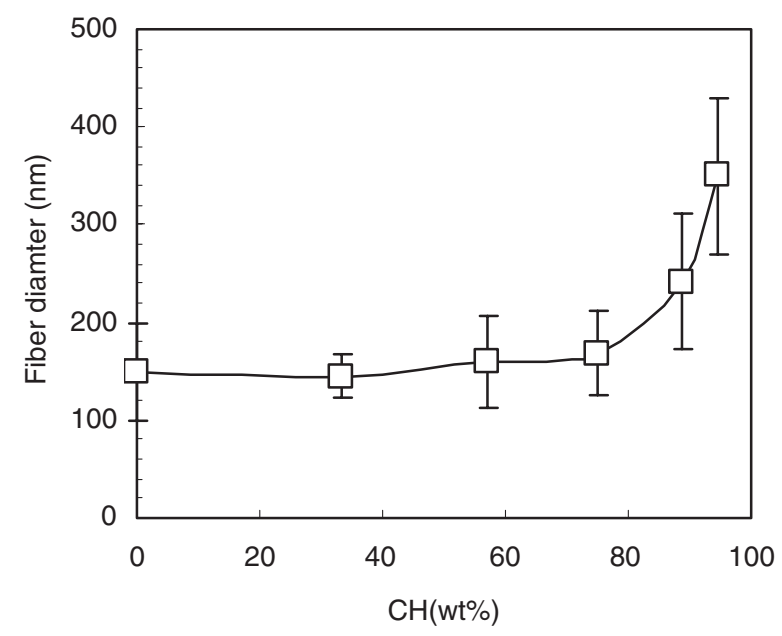

Figure 4. Polymer composition dependence of the diameter of fibers produced from $\mathrm{CH} / \mathrm{PEO}$ blend solutions $\mathrm{C} 13-\mathrm{C} 18$ (see Table I). The composition is denoted by wt $\% \mathrm{CH}$ calculated as $\mathrm{CH} /(\mathrm{CH}+\mathrm{PEO})(\mathrm{w} / \mathrm{w}) \times 100 \%$.

from $\mathrm{C} 18$ solution. The characteristic adsorption peaks were observed at 3365 and $1658 \mathrm{~cm}^{-1}$ for the $\mathrm{CH} / \mathrm{PEO}$ blend fabric. These peaks indicates the presence of $-\mathrm{OH}$ and $-\mathrm{NH}$ groups, and the presence of $\mathrm{C}=\mathrm{O}$ groups, respectively, derived from the chitosan component, which was undoubtedly involved in the fiber fabrication.

\section{Heating Effect on CHON/PEO Blend Solutions}

The properties of spraying $\mathrm{CHON} / \mathrm{PEO}$ solutions and their spinnability by ESD are summarized in Table II. At $25^{\circ} \mathrm{C}$, we could obtain spherically structured deposits from the blend solutions with lower CHON concentrations (S1-S4), but failed to spray

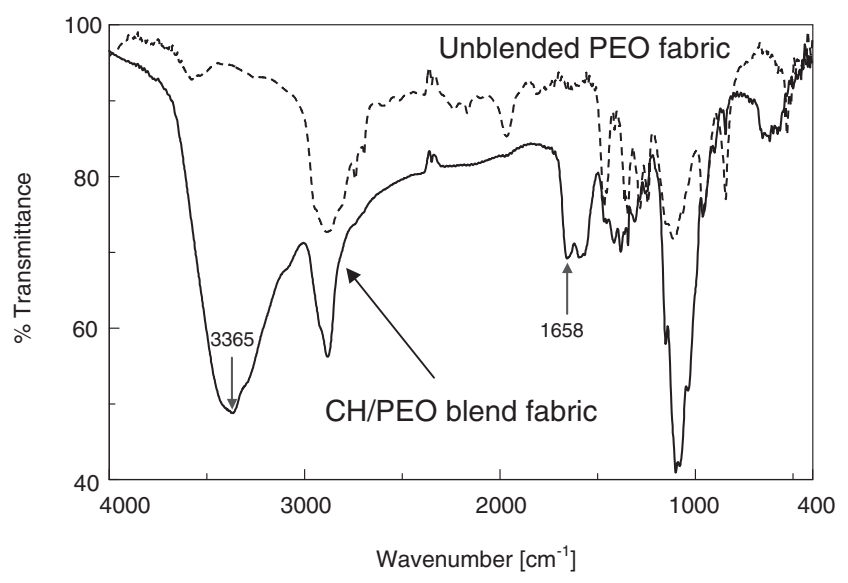

Figure 5. FT-IR spectrum of an electrospray-deposited $\mathrm{CH} /$ PEO blend fabric, compared with that of an unblended PEO fabric. These fabrics were sprayed from $\mathrm{C} 15$ and $\mathrm{C} 18$ solutions, respectively (see Table I).

the CHON/PEO solutions (S5-S12) with higher $\mathrm{CHON}$ concentrations. Therefore, we attempted to spray the relevant solutions heated at $70^{\circ} \mathrm{C}$ for 20 min. The solution viscosities then decreased by the heating treatment, e.g., from 15 to $6.27 \mathrm{mPas}$ for $\mathrm{S} 1$; from 103 to $31 \mathrm{mPas}$ for $\mathrm{S} 5$; and from 531 to 130 $\mathrm{mPas}$ for $\mathrm{S} 9$. The heating effect on the ESD processability and an effect of CHON concentration on the surface morphologies of electrospray-deposited fabrics are shown in Figure 6 for the cases from S1, S5, and S9 solutions, where the respective PEO concentrations are all fixed at $1 \mathrm{wt} \%$. Thus we could spray all the solutions at $70^{\circ} \mathrm{C}$. As demonstrated by SEM images in the Figure, the blend solutions with higher CHON concentrations tended to form a finer fibrous structure.

As seen in Table II, the conductivity of CHON/ PEO blend solutions increased with an increase in the CHON concentration. Therefore, the spraying voltage (but near the lower critical spraying voltage) also increased with an increase in the CHON concentration. ${ }^{8}$ Conversely, the viscosity of blend solutions decreased with an increase in the CHON concentration, because the molecular weight of CHON (110k) is considerably smaller than that of PEO (500k). There was thus a general trend that the spray solutions with higher PEO concentrations formed a fibrous structure by ESD; correspondingly, the solutions with a viscosity higher than $31 \mathrm{mPas}$ showed better spinnability. The diameter of fibers was in a narrow range $c a$. 150$200 \mathrm{~nm}$ and the effect of solution composition on the fiber diameter was less indicative.

\section{Heating Effect on PEC/PEO Blend Solutions}

The properties of spraying PEC/PEO solutions and their spinnability are summarized in Table III. At 


\section{H. SEO et al.}

Table II. Properties of CHON/PEO blend solutions and their spinnability by ESD

\begin{tabular}{cccccccccc}
\hline $\begin{array}{c}\text { Spray } \\
\text { Solution }\end{array}$ & $\begin{array}{c}\mathrm{CHON}^{\mathrm{a}}-110 \mathrm{k} \\
(\mathrm{g})\end{array}$ & $\begin{array}{c}\mathrm{PEO}^{\mathrm{b}}-500 \mathrm{k} \\
(\mathrm{g})\end{array}$ & $\begin{array}{c}\text { Water } \\
(\mathrm{g})\end{array}$ & $\begin{array}{c}\text { Conductivity } \\
(\mathrm{mS} / \mathrm{cm})\end{array}$ & $\begin{array}{c}\text { Viscosity* }^{*} \\
(\mathrm{mPas})\end{array}$ & $\begin{array}{c}\text { Surface tension } \\
(\mathrm{mN} / \mathrm{m})\end{array}$ & $\begin{array}{c}\text { Spraying } \\
\text { Temp. }\left({ }^{\circ} \mathrm{C}\right)\end{array}$ & $\begin{array}{c}\text { Spraying } \\
\text { Voltage }(\mathrm{kV})\end{array}$ & $\begin{array}{c}\text { Surface } \\
\mathrm{morphology}\end{array}$ \\
\hline S1 & 0.8 & 1 & 98.2 & 1.369 & 6.27 & 61.1 & 70 & 9.45 & spherical \\
S2 & 0.6 & 2 & 97.4 & 0.908 & 14.2 & 60.2 & 70 & 8.68 & s/f mixture \\
S3 & 0.4 & 3 & 96.6 & 0.613 & 40.1 & 58.8 & 70 & 7.61 & fibrous \\
S4 & 0.2 & 4 & 95.8 & 0.286 & 88.1 & 59.2 & 70 & 6.84 & fibrous \\
\hline S5 & 8 & 1 & 91 & 9.81 & 31 & 58.1 & 70 & 16.56 & fibrous \\
S6 & 6 & 2 & 92 & 7.36 & 42 & 59.3 & 70 & 14.38 fibrous \\
S7 & 4 & 3 & 93 & 4.22 & 60 & 56.1 & 70 & 11.30 & fibrous \\
S8 & 2 & 4 & 94 & 2.27 & 111 & 59.3 & 70 & 7.09 & fibrous \\
\hline S9 & 16 & 1 & 83 & 17.64 & 130 & 57.5 & 70 & 16.56 & fibrous \\
S10 & 12 & 2 & 86 & 12.11 & 150 & 59.2 & 70 & 14.86 & fibrous \\
S11 & 8 & 3 & 89 & 9.09 & 162 & 60.0 & 70 & 12.25 & fibrous \\
S12 & 4 & 4 & 92 & 4.59 & 160 & 57.5 & 70 & 12.20 & fibrous \\
\hline
\end{tabular}

${ }^{\mathrm{a}} \mathrm{CHON}$ : sodium condroitin sulfate; ${ }^{\mathrm{b}} \mathrm{PEO}$ : poly(ethylene oxide); ${ }^{\mathrm{c}} \mathrm{s} / \mathrm{f}$ mixture: mixture of spherical and fibrous shapes.

$*$ Viscosity data were measured at $70^{\circ} \mathrm{C}$. Other solution properties were measured at $25^{\circ} \mathrm{C}$.

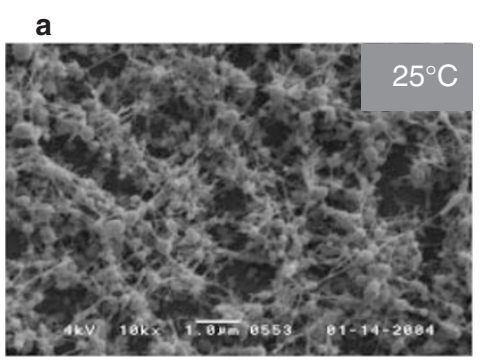

c

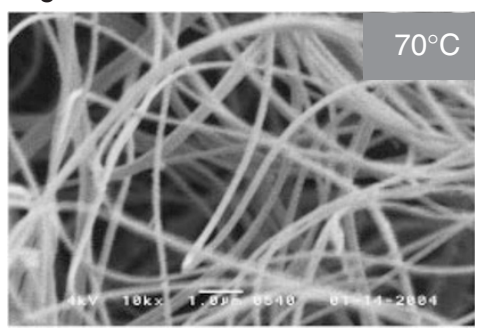

b

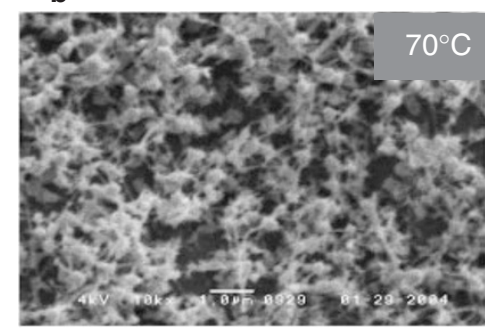

d

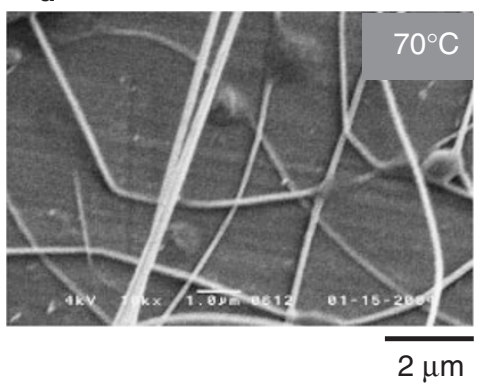

Figure 6. Heating effect on the ESD processability and CHON-concentration effect on the surface morphology of electrospray-deposited CHON/PEO blend fabrics: sprayed from (a) S1 solution at $25^{\circ} \mathrm{C}$ ( $\mathrm{S} 5$ and S9 solutions could not be sprayed at $25^{\circ} \mathrm{C}$.); (b) $\mathrm{S} 1$, (c) $\mathrm{S} 5$, and (d) S9 solutions at $70^{\circ} \mathrm{C}$ (see Table II).

$25^{\circ} \mathrm{C}$, we could deposit spherically structured deposits from the blend solutions with lower PEC concentrations (P1-P4), but failed to spray the PEC/PEO solutions (P5-P12) with higher PEC concentrations. Therefore, again, we attempted to spray the corresponding solutions heated at $70^{\circ} \mathrm{C}$. The solution viscosity decreased by the heating, e.g., from 29.7 to $13.2 \mathrm{mPas}$ for $\mathrm{P} 2$; from 71.8 to $30.4 \mathrm{mPas}$ for $\mathrm{P} 6$; and from 178 to $39.2 \mathrm{mPas}$ for P10. SEM photographs in Figure 7 indicate the heating effect on the ESD processability and an effect of PEC concentration on the surface morphologies of electrospray-deposited fabrics prepared from P2, P6, and P10 solutions, the PEO concentration being fixed at $2 \mathrm{wt} \%$ in any of the solutions. As demonstrated there, we could spray all solutions at $70^{\circ} \mathrm{C}$. The SEM observations revealed clearly a changing manner of the surface morphology from a spherical structure to a fibrous one via spindle-shaped stage with an elevation in the PEC concentration.

The conductivity of PEC/PEO blend solutions increased with an increase in the PEC concentration (see Table III), and hence the spraying voltages also increased correspondingly. ${ }^{8}$ Generally, the spraying solutions with higher PEO concentrations tended to form the fibrous structure by ESD, while the solutions with higher PEC concentrations tended to form the spherical structure in the deposition. The diameter of 
Table III. Properties of PEC/PEO blend solutions and their spinnability by ESD

\begin{tabular}{cccccccccc}
\hline $\begin{array}{c}\text { Spray } \\
\text { Solution }\end{array}$ & $\begin{array}{c}\text { PEC }^{\mathrm{a}}-510 \mathrm{k} \\
(\mathrm{g})\end{array}$ & $\begin{array}{c}\text { PEO }^{\mathrm{b}}-500 \mathrm{k} \\
(\mathrm{g})\end{array}$ & $\begin{array}{c}\text { Water } \\
(\mathrm{g})\end{array}$ & $\begin{array}{c}\text { Conductivity } \\
(\mathrm{mS} / \mathrm{cm})\end{array}$ & $\begin{array}{c}\text { Viscosity* } \\
(\mathrm{mPa})\end{array}$ & $\begin{array}{c}\text { Surface tension } \\
(\mathrm{mN} / \mathrm{m})\end{array}$ & $\begin{array}{c}\text { Spraying } \\
\text { Temp. }\left({ }^{\circ} \mathrm{C}\right)\end{array}$ & $\begin{array}{c}\text { Spraying } \\
\text { Voltage }(\mathrm{kV})\end{array}$ & $\begin{array}{c}\text { Surface } \\
\mathrm{morphology}\end{array}$ \\
\hline P1 & 0.8 & 1 & 98.2 & 0.397 & 4.4 & 56.4 & 70 & 14.86 & spherical \\
P2 & 0.6 & 2 & 97.4 & 0.298 & 13.2 & 59.6 & 70 & 11.79 & $\begin{array}{c}\text { spherical } \\
\text { s.09 }\end{array}$ \\
P3 & 0.4 & 3 & 96.6 & 0.198 & 32.7 & 58.1 & 70 & s/f mixture \\
P4 & 0.2 & 4 & 95.8 & 0.103 & 53.5 & 57.8 & 70 & 7.51 & fibrous \\
\hline P5 & 2.4 & 1 & 96.6 & 0.805 & 25.8 & 59.2 & 70 & 15.47 & spherical \\
P6 & 1.8 & 2 & 96.2 & 0.655 & 30.4 & 59.6 & 70 & 13.79 & spindle-shaped \\
P7 & 1.2 & 3 & 95.8 & 0.425 & 28.0 & 58.1 & 70 & 8.67 & fibrous \\
P8 & 0.6 & 4 & 95.4 & 0.209 & 25.8 & 57.8 & 70 & 7.16 & fibrous \\
\hline P9 & 4 & 1 & 95 & 1.140 & 41.5 & 58.0 & 70 & 16.52 & spherical \\
P10 & 3 & 2 & 95 & 0.901 & 39.2 & 54.8 & 70 & 15.89 & fibrous \\
P11 & 2 & 3 & 95 & 0.623 & 32.1 & 59.0 & 70 & 13.78 & fibrous \\
P12 & 1 & 4 & 95 & 0.349 & 35.6 & 61.3 & 70 & 10.89 & fibrous \\
\hline
\end{tabular}

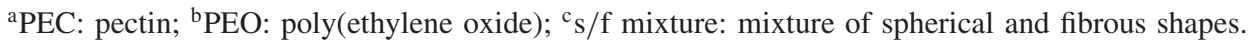

${ }^{*}$ Viscosity data were measured at $70^{\circ} \mathrm{C}$. Other solution properties were measured at $25^{\circ} \mathrm{C}$.
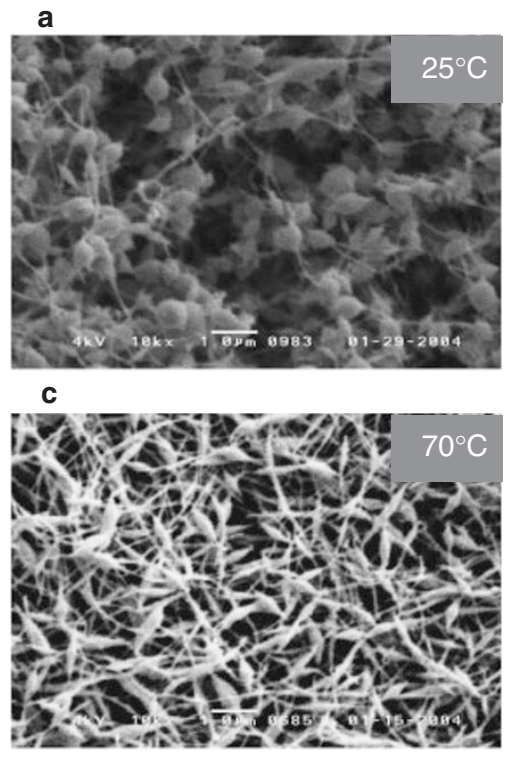

b

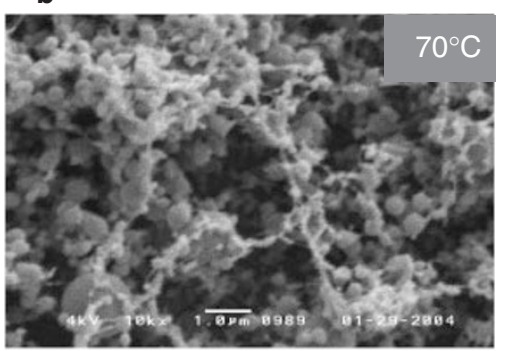

d

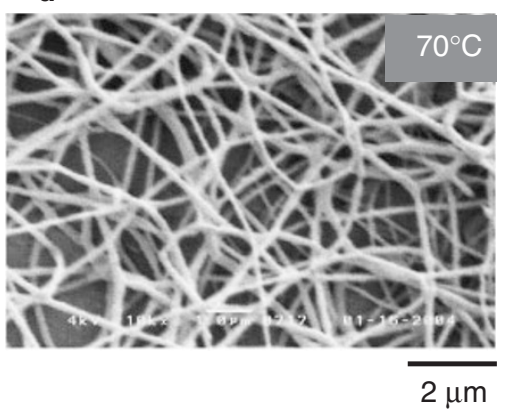

Figure 7. Heating effect on the ESD processability and PEC-concentration effect on the surface morphology of electrospray-deposited PEC/PEO blend fabrics: sprayed from (a) P2 solution at $25^{\circ} \mathrm{C}$ (P6 and P10 solutions could not be sprayed at $25^{\circ} \mathrm{C}$.); (b) P2, (c) P6, and (d) P10 solutions at $70^{\circ} \mathrm{C}$ (see Table III).

the produced fibers was about $100 \mathrm{~nm}$ and the effect of solution composition on the fiber diameter could be undiscernible for this system, too.

\section{CONCLUSIONS}

Chitosan, chondroitin sulfate, and pectin nanofibrous fabrics were prepared successfully from the respective polysaccharide/PEO blend solutions by ESD. The effect of PEO addition, and that of the molecular weight and concentration on the formation of the structure and morphology of the produced fabrics were systematically examined. The addition of PEO with higher-molecular-weights and/or at higher concentrations improved significantly the electrostatic spinnability of the chitosan $(\mathrm{CH})$ solutions. The high-molecular-weight PEO was also advantageous for the fibrous formation even if the addition amount was small: a $\mathrm{CH}$ solution blended with only 0.5 wt $\%$ PEO was already effective for the fiber formation. An optimal viscosity limit for the fiber formation from the $\mathrm{CH} / \mathrm{PEO}$ blend solutions was determined as $>95.5 \mathrm{mPas}$. The heating of the spraying solutions at $70^{\circ} \mathrm{C}$ enhanced the electrostatic fiber formation from both solutions of chondroitin sulfate $(\mathrm{CHON}) / \mathrm{PEO}$ and pectin (PEC)/PEO blends. We accomplished well 
the fiber formations of chondroitin sulfate and of pectin by the combined use of PEO addition and hightemperature ESD. Further studies on characterization of the polysaccharide/PEO blend fabrics insolubilized after their deposition are now in progress and the result will be reported elsewhere.

Acknowledgment. This work was partly supported by a Grant-in-Aid for Young Scientists (B) (No. 15710104 to H. M.) from the Ministry of Education, Culture, Sports, Science, and Technology, Japan.

\section{REFERENCES}

1. G. M. H. Meesters, P. H. W. Vercoulen, J. C. Marijnissen, and M. B. Scarlett, J. Aerosol Sci., 23, 37 (1992).

2. C. Chen, E. M. Kelder, P. J. J. M. van der Put, and J. Schoonman, J. Mater. Chem., 6, 765 (1996).

3. B. Hoyer, G. Sørensen, N. Jensen, D. B. Nielsen, and B. Larsen, Anal. Chem., 68, 21 (1996).

4. V. N. Morozov, T. Ya. Morozova, and N. R. Kallenbach, Int. J. Mass Spectrom., 178, 143 (1998).

5. K. Morota, A. Tanioka, Y. Yamagata, and K. Inoue, Kobunshi Ronbunshu, 59, 706 (2002).

6. K. Morota, A. Tanioka, Y. Yamagata, and K. Inoue, Kobunshi Ronbunshu, 59, 710 (2002).

7. I. Uematsu, H. Matsumoto, K. Morota, M. Minagawa, A. Tanioka, Y. Yamagata, and K. Inoue, J. Colloid Interface Sci., 269, 336 (2004).

8. K. Morota, H. Matsumoto, T. Mizukoshi, Y. Konosu, M. Minagawa, A. Tanioka, Y. Yamagata, and K. Inoue, J. Colloid Interface Sci., 279, 484 (2004).

9. H. Matsumoto, M. Minagawa, A. Tanioka, and Y. Yamagata, J. Jpn. Soc. Abrasive Technol., 49, 36 (2005).

10. H. Matsumoto, T. Mizukoshi, K. Nitta, M. Minagawa, and A. Tanioka, Y. Yamagata, J. Colloid Interface Sci., in press (2005).

11. R. A. A. Muzzarelli, "Chitin," Pergamon Press, Oxford,
U.K., 1977, p 94.

12. D. A. Carrino and A. I. Caplan, Matrix Biol., 14, 121 (1994).

13. G. W. White, T. Katona, and J. P. Zodda, J. Pharm. Biomed. Anal., 20, 905 (1999).

14. G. Abatangelo, R. Barbucci, P. Brun, and S. Lamponi, Biomaterials, 18, 1411 (1997).

15. L. L. Lloyd, J. F. Kennedy, P. Methacanon, M. Paterson, and C. J. Knill, Carbohydr. Polym., 37, 315 (1998).

16. H. Seo, K. Mitsuhashi, and H. Tanibe, in "Advances in Chitin and Chitosan," C. J. Brine, P. A. Sandford, and J. P. Zikakis, Ed., Elsevier Science Publishers Ltd., Barking, U.K., 1992, p 34.

17. J. Doshi and D. H. Reneker, J. Electrostat., 35, 151 (1995).

18. D. H. Reneker and I. Chun, Nanotechnology, 7, 216 (1996).

19. Y. Dzenis, Science, 304, 1917 (2004).

20. W.-J. Li, C. T. Laurencin, E. J. Caterson, R. S. Tuan, and F. K. Ko, J. Biomed. Mater. Res., 60, 613 (2002).

21. K. Kim, Y. K. Luu, C. Chang, D. Fang, B. S. Hsiao, and B. Chu, J. Controlled Release, 98, 47 (2004).

22. W. K. Son, J. H. Youk, and W. H. Park, Biomacromolecules, 5, 197 (2004).

23. H. Jiang, D. Fang, B. S. Hsiao, B. Chu, and W. Chen, Biomacromolecules, 5, 326 (2004).

24. I. C. Um, D. Fang, B. S. Hsiao, A. Okamoto, and B. Chu, Biomacromolecules, 5, 1428 (2004).

25. B.-M. Min, S. W. Lee, J. N. Lim, Y. You, T. S. Lee, P. H. Kang, and W. H. Park, Polymer, 45, 7137 (2004).

26. K. Ohkawa, D. Cha, H. Kim, A. Nishida, and H. Yamamoto, Macromol. Rapid Commun., 25, 1600 (2004).

27. B. Duan, C. Dong, X. Yuan, and K. Yao, J. Biomater. Sci. Polymer Ed., 15, 797 (2004).

28. B. Ding, E. Kimura, T. Sato, S. Fujita, and S. Shiratori, Polymer, 45, 1895 (2004).

29. J. D. Andrade, V. Hlady, and S. I. Jeon, in "Hydrophilic Polymers," J. E. Glass, Ed., American Chemical Society, Washington D.C., 1996.

30. H.-J. Jin, S. V. Fridrikh, G. C. Rutledge, and D. L. Kaplan, Biomacromolecules, 3, 1233 (2002). 